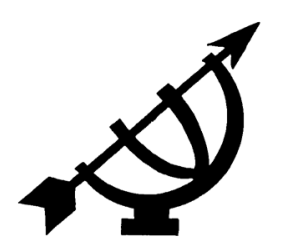

\title{
Creating intentionally inviting schools through professional development: an appreciative inquiry
}

\author{
G.M. Steyn \\ Department of Further Teacher Education \\ University of South Africa \\ PRETORIA
}

E-mail: steyngm1@unisa.ac.za

\section{Creating intentionally inviting schools through professional development: an appreciative inquiry}

The professional development (PD) of teachers plays an important role in schools; it is indispensable for continuous school development. When schools are exposed to new approaches to learning and teaching, teachers are granted the opportunities to change their thinking and behaviour. In 2009, two South African schools with specific inviting characteristics were nominated for the inviting school award given by the International Alliance for Invitational Education (IAIE). However, the inviting characteristics of these schools were not explicitly intentional according to the IE philosophy, therefore they had to follow a professional development programme aimed at raising teachers' awareness of invitational education (IE). Workshops were held to equip staff members with IE knowledge and skills, and to increase their understanding of their current practices with a view of making them more intentionally inviting.

The study focused on the following two questions: What are the positive experiences of teaching staff concerning the current approach to teaching and learning in schools?; and What strategies may be introduced to assist teachers and their schools in becoming intentionally inviting? These two questions are based on appreciative inquiry (AI) and IE. A qualitative research design was most appropriate for the purpose of this study. An analysis of the data revealed two categories (the discovery phase: discovering the best of what exists in the school and the dreaming phase: creating a new future) on which $A$ l is based. 
Die skepping van doelbewus-uitnodigende skole deur middel
van professionele ontwikkeling: 'n waarderende ondersoek

Die professionele ontwikkeling (PO) van onderwysers is baie belangrik in skole, aangesien dit noodsaaklik is vir voortdurende skoolontwikkeling. Wanneer skole kennis maak met nuwe onderrig- en leerbenaderings, kry onderwysers die geleentheid om hulle denke en gedrag te verander. Twee Suid-Afrikaanse skole met bepaalde uitnodigende kenmerke is aan die einde van 2009 genomineer vir die International Alliance for Invitational Education (IAIE) se toekenning aan uitnodigende skole. Hierdie skole het hulle nie doelbewus daarop toegespits om meer uitnodigend te wees in ooreenstemming met die filosofie van uitnodigende onderwys nie en moes daarom 'n professionele ontwikkelingsprogram volg waartydens onderwysers bewus gemaak is van uitnodigende onderrig ("invitational education" [IE]). Die werkswinkels waaruit die program bestaan het, was daarop gemik om onderwysers toe te rus met IE-kennis en -vaardighede, en om 'n begrip van hulle huidige werkswyses te bewerkstellig, sodat hulle doelbewus meer uitnodigend te werk kon gaan. Die studie het op die volgende twee vrae gefokus: Wat is die onderrigpersoneel se positiewe ervarings van die heersende benadering tot onderrig en leer in die skool?; en Watter strategieë kan onderwysers implementeer sodat hulle en hulle skole meer doelbewus uitnodigend kan word? Hierdie twee vrae vind hulle grondslag in die waarderingsondersoek ("appreciative inquiry" [AI]) en in IE. 'n Kwalitatiewe navorsingsontwerp was geskik vir die studie. Twee kategorieë wat op Al gegrond is (die ontdekkingsfase: ontdekking van die beste wat in die skool bestaan en die droomfase: skepping van 'n nuwe toekoms) het aan die lig gekom tydens die ontleding van die data.

\section{Introduction}

Current research reveals that professional development (PD) is the key to improved teaching and learning environments in schools (Negrioni, 2005; Meiers \& Ingvarson, 2005; Desimone et al., 2006; Smith \& Gillespie, 2007; Vemić, 2007:209). Other studies confirm the significance of PD, “... where it is identified and implemented within the school context to meet the needs of their teachers and students, for the continuous improvement of professional practice" (Australia, 2008). PD is also indispensable to continuous school development and ultimately to improving learner performance (Hong Kong, 2006:1). In this regard Doring (2002:6) states that the "... challenge for schools is to enact a deliberate, effective learning culture". When schools are exposed to new approaches emerging from 
research and developments, teachers may change their thinking and behaviour in their approach to teaching, which may lead to learner improvement (Smith \& Gillespie, 2007:215).

The job-embedded professional development model shows that PD is located within local contexts such as schools as part of an attempt to establish ongoing professional communities (Galloway, 2004; Smith \& Gillespie, 2007). This model is based on the belief that "... one cannot take individual teachers out of their environment, train and change them, then put them back into the same environment and expect them to change that environment" (Smith \& Gillespie, 2007:233). Furthermore, learning in professional communities takes place at three levels: the individual, workplace and school levels (Anon., 2007). Invitational education (IE) as an example of a professional development programme for schools that is maintained by the International Alliance for Invitational Education (IAIE) as a means of transforming school climates and classrooms with a view to improve student performance (Asbill \& Gonzalez, 2000:24).

Although teachers' PD has long been the focus of research, a great deal still needs to be learnt about staff experiences of professional growth in the school (Kitchen, 2009:46). Consistent guidelines for PD planning and implementation that may develop the school are emerging from the body of research on PD. In essence, PD can be viewed as the "... bridge between where [we] are now and where [we] need to be to meet the new challenges of guiding all students in achieving higher standards of learning and development" (Building bridges as quoted in Anon., 2007). The purpose of this study is to describe how schools can become intentionally inviting in terms of their current approach to teaching and learning. It addresses the following two questions: What are the positive experiences of teaching staff concerning the current approach to teaching and learning in the schools?; and What strategies may be introduced to assist teachers and their schools to become intentionally inviting? These two questions are firmly based on appreciative inquiry $(\mathrm{Al})$ and invitational education (IE). Al strives to build on what works satisfactorily in situations and organisations (Bushe, 2007:33; Billings \& Kowalski, 2008 ) and therefore views questions in "a significantly different way" (Preskill \& Catsambas, 2006:1). Although research on the PD of staff is often done in a problem-based context, this study uses a different and more positive approach. By determining which aspects in the school meet the requirements of the IE model, the AI model can build on the best practices of the past with a view to improving 
teachers' attitudes and behaviour as well as the school culture and ensuring that they become intentionally inviting.

\section{Conceptual framework}

Invitational education (IE) is regarded as a philosophy and a set of activities aimed at promoting a total school climate that is welcoming and that intentionally energises people to realise their individual and collective potential (Purkey \& Aspy, 2003; Novak \& Purkey, 2001). For more than two decades, supporters of Invitational Education have been advocating for schools and educational institutions where all learners feel welcome and are invited to succeed. Currently Invitational Education is actively practised in many schools in the world (Hunter \& Smith, 2007:8). Studies show how IE facilitates the achievement of learners' personal potential and changes forces in schools that could destroy such potential (Hunter \& Smith, 2007; Gresham, 2007). According to the IE approach, everything in and around schools, including every individual, either adds to or subtracts from the process of being "a beneficial presence in the life of oneself and others, personally and professionally" (Purkey \& Aspy, 2003:148). This implies that staff should be equipped with the knowledge, skills and attitudes to realise and maintain an atmosphere that invites human interaction in the school. It is based on certain key aspects that involve communicating caring and appropriate messages intended to invite the development of human potential (Novak \& Purkey, 2001; Kok \& Van der Merwe, 2002). These assumptions are (Purkey \& Aspy, 2003; Schmidt, 2004; Hunter \& Smith, 2007) as follows:

- Respect. People are able, valuable and responsible, and should be treated accordingly. Respect starts with self-respect that develops integrity and unites a person's thoughts, feelings and actions in a new cycle of personal empowerment (Dreher, 2002: 207).

- Trust. Education is a collaborative, cooperative activity. To promote interdependency education has to involve everyone, because people are fundamentally interdependent. Through interpersonal communication an atmosphere of trust may be enhanced, that will enable people to share information and work together to promote the school's effectiveness (Dreher, 2002:209).

- Optimism. People possess untapped potential in all areas of development. If staff members are optimistic about what individual learners can become, they need to create an environment 
that nurtures everybody and allows them all to develop their unlimited potential.

- Intentionality. Human potential is best realised if places, policies, processes and programmes are specifically designed to invite development, and people are personally and professionally inviting in their approach to self and others. Inviting teachers attempt to sustain an environment characterised by both direction and purpose.

- Care. The process is the "product in the making". In IE, care is the continuous desire to "link significant personal means with worthwhile societal ends" (Novak \& Purkey, 2001:14).

According to the IE model, there are five factors that play a role in the intentional creation of a school in which every individual person is warmly invited to develop his/her full potential. These factors are people, places, policies, programmes and processes (Novak \& Purkey, 2001:15). Essentially the main purpose of IE is to develop a school culture that is more enriching, satisfying and exciting for everyone in the school (Egley, 2003:58; Paxton, 2003:23). The assessment criteria used by the International Alliance for Invitational Education (IAIE) for awarding the IE honour to schools are based on the following (Inviting School Award, 2010):

- Is everyone associated with the school able, valuable and responsible?

- Is education in the school a cooperative and collaborative activity where process is as important as product?

- Is there a belief in the school that learners and staff alike possess untapped potential in all areas of development?

- Does your school create and maintain places, policies, processes and programmes designed to "invite" development and people who are intentionally inviting in their approach to self and others, both personally and professionally?

The conceptual framework of IE aligns with appreciative inquiry (AI) since the latter also focuses on "positive aspects of human nature and development as the catalysts for organizational change" (Lehner \& Hight, 2006:142). In their seminal work, Cooperrider and Srivasta (1987) developed the Al technique which positively focuses on what works well in organisations or situations (Lewis \& Van Tiem, 2004:21-22). Al builds on the "positive psychology of Seligman in the late 1990s" (Billings \& Kowalski, 2008:104) which "is a research 
perspective, research method and world view" (Calbrese et al., 2007:278). It is defined as the study of what is the best in people, organisations and the life world (Lewis \& Van Tiem, 2004). Employing an Al perspective indicates an attempt to identify the participants' positive perception of their current school climate with their intention to improve themselves and the school, and to convey the assumptions of IE (Cooperrider \& Srivastva, 1987; Calbrese et al., 2007:279). For the purpose of this study, the following principles of Al are mentioned (Lehner \& Hight, 2006:142):

- Constructionist principle. Individuals (adult learners) construct their own reality. The Al approach is based on the premise that individuals construct meaning and their reality (Calbrese et al., 2007:279). They have accumulated considerable knowledge and numerous life experiences that include previous education experiences and work-related activities. In terms of these, such learners are able to construct new knowledge and understanding from their existing knowledge and understanding, and then interpret their meaning and significance (Chalmers \& Keown, 2006; Darling, 2008; Darling-Hammond \& Richardson, 2009; Hodkinson \& Hodkinson, 2005). Moreover, teachers learn best when they work in professional communities characterised by dialogue and action (Wenger, 2007). Collaborative learning implies that all staff members in the organisation (school) should develop a learning attitude that encourages them to set out intentionally to improve the system (Dixon, 1998:164). The responsibility for individual learning has to be shared between the organisation and individuals (Martensson, 2000:214). The focus should be on the collective competence in the workplace and not exclusively on the development of each individual's competence. This presumes an emphasis on social interaction within schools.

- Simultaneity principle. The act of inquiry initiates the discovery of possibilities for building the future (Lehner \& Hight, 2006:143). Inquiry sets the stage for change (Dunlap, 2008:25) since adult learners are able to interpret the meaning and significance of the discovered possibilities (Chalmers \& Keown, 2006; Darling, 2008; Darling-Hammond \& Richardson, 2009; Hodkinson \& Hodkinson, 2005).

Cooperrider and Srivastva (1987) developed the appreciative inquiry (Al) technique in their seminal work. Al focuses on what works well in situations and organisations. The Al model consists of a "Four Ds" cycle: 
- Discovery. This phase entails an appreciation of what currently exists: "the best of what has been and what is" (Dunlap, 2008:26; Lehner \& Hight, 2006:143; Schutt, 2007:23). In this phase the aim is to "build on the positive core" (Schutt, 2007:27) by expecting participants to explain their personal perception of a particular phenomenon in their situation or organisation (Bushe \& Kassam, 2005:167; Elleven, 2007:451), in this case the current school climate.

- Dreaming. The second phase entails imagining what could be and attempting to envision the results after new strategies have been implemented (Dunlap, 2008:26; Elleven, 2007:451; Schutt, 2007:23). In short, this phase involves the creation of a new vision for the future (Lehner \& Hight, 2006:145).

- The other two phases, namely design (what should be) (Schutt, 2007; Dunlap, 2008) and destiny (creating what will be) (Bushe \& Kassam, 2005; Schutt, 2007), could be the focus of further studies once participants have intentionally implemented certain aspects of the IE model in their practice.

The Al theoretical perspective allowed the researcher to identify staff members' positive perceptions of their current school climate and it also showed their desire to improve their current practice to become intentionally inviting in accordance with the IE model. By highlighting and determining what is currently working well in the schools, the Al model builds on the best of the past in order to improve the school climate. This study, therefore, shows how teaching staff construct meaning and interpret the perceptions of their practice and their understanding of IE.

The author has been "emphatically immersed" in the study (Maree \& Van der Westhuizen, 2010:33) and believes that human beings develop through certain phases throughout their lives. She believes that this is also true for professionals in the teaching profession. Vygotsky's (1978) theories of development are appropriate for the professional development of teachers. Through structured, formal professional development professionals are equipped with skills and knowledge to assist their professional growth. "Grounding professional development within Vygotsky's theories of development seems most appropriate, not only because of the emphasis on the concept of development they share, but also more importantly due to the fact that both professional development and Vygotsky's theories of development consider social interaction to be the main source underlying human development" (Barohny, 2008:145). The 
main aim of $P D$ is to enhance learner performance through increased teacher effectiveness.

Based on the above the viewpoint of the researcher can be summarised as follows:

- Both people and organisations face numerous challenges, but seen through a positive lens such challenges can be addressed successfully. This viewpoint is supported by both appreciative inquiry and the invitational education approach.

- Human development is natural and includes the development of professionals in the teaching profession. Professionals possess untapped abilities that can be developed through appropriate PD programmes and professional communities. Invitational education as an approach, strives to create such a conducive environment in schools.

- For organisations (and schools) to prosper, it is important that they discover their current strengths with a view to build a better future. For the sake of effective professional development, it is important to create a favourable school environment for teaching and learning.

\section{Research design}

Two South African primary schools have been purposefully selected as sites for workplace learning and IE. These schools were nominated at the end of 2009 by the author and a principal whose school received the invitational education award in 1993 and who is also a member of the International Alliance for Invitational Education (IAIE). The schools displayed certain inviting characteristics that qualified them to be nominated as inviting schools by the IAIE. However, since these characteristics were not explicitly intentional according to the IE philosophy, the schools needed assistance in the form of a PD programme to to raise awareness of IE. The ultimate aim of the workshops was to equip the staff with the necessary knowledge, skills and attitude concerning IE and to facilitate their understanding of their current practices with a view of making them more intentionally inviting. To develop and "reculture" a school to become intentionally inviting requires an orchestrated effort within the school (Bernauer, 2002:90).

At the time of writing, both these schools were preparing for their IE application and the author acted as a facilitator and consultant to assist the schools to meet the IAIE criteria for inviting schools. 
Although principals and senior management teams of the schools were familiar with the philosophy of invitational education, very few staff understood either the approach to, or the implications of, their practice. To compensate for this, an IE awareness programme was conducted to prepare all staff members for their IE applications and the intentional implementation of IE. The awareness programmes ran in December 2009 for School A and in January 2010 for School B.

The schools are primary, urban schools located in different suburbs in Gauteng, South Africa. Since both schools are interested in the quality of education, they employ additional teachers to reduce the teacher-learner ratio of $1: 40$ as far as possible. There are 1015 learners in School A, which caters for Grade R to Grade 7 learners. The state funds the salaries of 24 teachers, but the school employs 23 additional staff members. The learners come from middle-class to upper-class communities. Only 4\% of learners in 2009 were exempt from school fees, indicating the socioeconomic status of the school. In School B there are 1525 learners ranging from Grade R to Grade 7. Of the 67 academic staff members, 36 are funded by the state. The learners in this school are from an average to aboveaverage socioeconomic sector and only $1,75 \%$ of learners are exempt of school fees. Both schools employ educational psychologists to assist learners in need as well as a number of other support staff to ensure the smooth running of the school. They offer a wide variety of extramural cultural and sports activities.

For the purpose of this study, a qualitative research design incorporating aspects of exploratory, descriptive and contextual research (Corbin \& Strauss, 2008; McMillan \& Schumacher, 2006) was most appropriate. The data collection involved naïve sketches (Giorgi, 1985) from all staff members after each workshop conducted at the school. Where responses were not immediately clear, the researcher contacted the schools via e-mail to clarify their meaning. An interview with the principal of School B was also necessary to clarify some issues arising from the naïve sketches of participants in the school. This interview was recorded and transcribed, and field notes were taken during the interview.

The naïve sketches, which involved frank descriptions, notes or short stories on particular phenomena (Giorgi, 1985) were particularly beneficial in the context of this study. After each workshop, participants were requested to report on two questions in their naïve sketches. In total 38 naïve sketches were collected from School A and 45 from School B. The participants were required to respond to 
the following questions: Considering the IE model, what do you think is positive in your current approach to teaching and learning in the school?; and What would you suggest to make this approach more inviting? Responses to the first question in particular revealed current positive perceptions of the school. These relate to the first phase of Al, namely discovery. The second question encouraged participants to consider changes to be made to their current practices to meet the requirements of IE, which in essence focuses on the second phase of Al, namely the dreaming phase. Since some of the participants answered questions in Afrikaans, their responses were translated into English with due regard for the idiom of the language.

The model proposed by Lincoln and Guba (1985) was used to ensure trustworthiness, that is credibility, transferability, dependability and confirmability. Credibility was attained by obtaining naïve sketches, e-mail correspondence, member checking through e-mails to the principals of both schools, as well as a clarifying interview (including field notes) with the principal of School B. The thick transcription of naïve sketches in conjunction with the description of the research methodology ensured transferability. A description of each setting, the data collection and the research methodology, and involvement of all participants in both workshops ensured dependability. Triangulation (described above) and reflectivity ensured confirmability.

Tesch's descriptive open coding was used to analyse the data (Creswell, 2007). A sense of the whole was gained by reading the naïve sketches, e-mail correspondence and the transcription of the interview.

\section{Findings}

Categories and subcategories relating to the two questions and $\mathrm{Al}$ (discovery and dreaming) emerged from the data, namely the discovery phase: discovering the best of what exists in the school; and the dreaming phase: creating a new future. A literature study provides a framework for contrasting the findings of this study with those of others (Creswell, 2007).

\subsection{The discovery phase: discovering the best of what exists in the school}

The discovery phase highlights a number of positive aspects that currently exist in the schools. In vivo codes, which include the "exact 
words used by participants" (Creswell, 2007:153), assist with expanding the understanding of the findings. The following subcategories have been identified: A nurturing school atmosphere: "I come to school with a song in my heart"; approach to learners: developing "a passion for working with kids"; physical resources: "beautiful" schools, "good facilities" and its "smooth running"; and the role of the principal: "incredible leadership". These aspects had a powerful influence on the nomination of these schools for the inviting school award.

\subsubsection{A nurturing school atmosphere: "I come to school with a song in my heart"}

A number of participants consider the atmosphere in their schools to be conducive to teaching and learning. The way in which they express their views shows that they are grateful that they work in their particular schools. Comments include the following: "I come to school each day with a song in my heart"; "There is a good spirit and atmosphere among staff"; The schools take "pains to build relationships"; and "There's always a peaceful atmosphere despite the crowded programme".

The schools are also characterised by "good teachers" who are regarded as "a highly competent body of teachers and fine role models". Participants refer to cooperation between staff, cooperation by management as well as "comradeship among teachers" who can "rely on one another". The collegiality between staff members in the schools is what is considered to be a major support system - it plays a significant role in their teaching practice. Some of the views expressed to support such a conclusion include "excellent collegial support, encouragement and affection", and the sharing of responsibilities and duties to lighten their workload. One participant writes: "The people I have to work with, WORK for me; it's good to have such a network of colleagues." They all "work very hard and are proud of the school". In the process "big goals are achieved without stepping on other people's toes or getting on their nerves". For some participants the professional and managerial support they receive in schools is outstanding. Another participant comments, "One never needs to solve a problem on one's own."

Staff members particularly value the sense of belonging in these schools that was in effect before the intervention. The schools strive to build relationships, to bear teachers' burdens and to be concerned about the welfare of all staff. Teachers arrange weekend breaks and staff get-togethers to strengthen their personal ties. 
During morning meetings they share good and bad news with other staff members in order to provide support to each other. For instance, flowers are sent to staff members who have been hospitalised. Comments that support this include the following: "Everyone here - the principal, school management and everybody else - has a strong sense of belonging. We want to be here and we form a close unity"; and "We have a book in which requests for prayer may be recorded". One participant mentioned that the school offers counselling to staff members:

Those who are going through divorces - the school is there to help. The school helps financially. There was one person battling with an alcohol problem and we could bear half the burden - that's rand for rand. It's the same with staff who want to study. If the teacher passes, the school repays half the tuition fee at the end of the year. Every year top performers are nominated to go abroad; the school pays all the expenses of sending them to England.

These findings are supported by literature stating that teachers need a community of teachers within the school to enable them to "learn together about their work as they apply that learning" (Smith \& Gillespie, 2007:233). Collaborating teachers complement one another's skills and knowledge, thereby broadening their perspectives (Dymoke \& Harrison, 2006:78; Lee, 2005:45). The findings also show adherence to the second and third assumptions of IE. The schools indicate that the education in their schools is collaborative and cooperative, and that staff make a collective effort to respect themselves and others personally and professionally. A collaborative culture in schools is considered to be conducive to the facilitation of learning (Rhodes \& Houghton-Hill, 2000:432). Apart from a nurturing school atmosphere, learners should be the main focus of developing schools. The "child-friendly" environment was raised by a few participants.

\subsubsection{Approach to learners: developing "a passion for working with kids"}

Many of the participants confirm their "commitment" to a "passion" for learners. They expose learners to many activities that foster their personal growth. They refer to the positive way in which staff approach and encourage learners, even when learners need to be disciplined. One participant writes: "I realise that I'm working with precious kids and I owe the best to them and to myself. I see invitational education as 'paying forward'." 
The reward systems in the schools show staff's commitment to rewarding and sustaining good learner performance. Every child is acknowledged, even if only for good progress in one subject. As a reward, learners receive merit certificates and handshakes from the principal. The participants believe that, once teachers view their learners positively and encourage learners through continuous support and assistance, they help their learners to develop their full potential - the ultimate aim of education. One participant blames teachers who abused their power when he/she was still at school. As a result this participant "vowed never ever [to] be like that. I've been a teacher for 13 years and I have never abused my power in the classroom."

Another participant's attitude to learners is expressed in the following statement: "I have a passion for improving children's self-image. Children who believe in themselves, believe that other people also believe in them - and miracles happen!"

Such findings are supported by those of Van Veen and Sleegers (2006:89) who write: "Teachers have very personal and strong views on how they think they should work." Teachers' perception of their work also forms an indispensable part of their professional identity (Van Veen \& Sleegers, 2006:106). Teachers' commitment to their own growth and the right attitude to their work are vital for effective teaching and learning (Moswela, 2006; Van Eekelen et al., 2006).

The teachers' comments lend support to constructivist theories that suggest that teachers as adults accumulate knowledge and numerous life experiences which assist them with constructing new knowledge and understanding, and interpreting their meaning and significance. The findings also conform to the first and third assumptions of IE, namely that people are able, valuable and responsible, and should be treated accordingly; and that teachers are optimistic about what individual learners can become and therefore create an environment that nurtures learners and allows them to develop their unlimited potential. Such an environment also includes the physical environment in which education takes place.

\subsubsection{Physical resources: "beautiful" schools, "good facilities", and "smooth running"}

Participants express their gratitude for the physical appearance of the schools, including the school grounds, classrooms, halls, corridors, gardens, offices and the teaching and learning equipment. They also appreciate the location of the schools in excellent 
neighbourhoods and the smooth running of their schools. Since many governing body positions for staff have been created, the schools offer good services like "smaller classes, which mean more personal attention to pupils". Participants indicate that there is "good planning" and that staff members know exactly what is expected of them. During the interview the principal of School B explained how the school functions in this regard:

I have a book entitled ' $X$ 's [name withheld] planning book'. [He showed me the book.] From September onwards we start drawing up new timetables for the next year. I draw up three timetables: one for five days, one for six days and one for seven days, and they [the staff] pick one ... I ask teachers to see which timetable works best and they make their recommendations ... We don't do things at the last moment ... Teachers are given a list of duties - a quarterly programme, an annual programme ... The work schedule spells it out: this one for sport, that one for culture ... Everyone knows precisely what's expected.

The principal also expresses his appreciation for the contribution of parent committees to the smooth running of the school. They "listen to all the complaints. Some breakers still get through, but it isn't a tsunami ... I usually say the pebble must be taken out of the shoe before a blister forms."

The quality of teaching and learning depends on people and resources, which are influenced by the community context, policies and programmes (King \& Newman, 2001:88). Within such a system the principal of a school plays a key role. Once again the findings indicate adherence to the fourth IE assumption that states that human potential is best realised by places, policies, processes and programmes that are specifically designed to invite development, and people who are personally and professionally inviting in their approach to self and others. Contextual factors such as school leadership, school policies and the supportiveness of the school community influence the development of professional knowledge (Meiers \& Ingvarson, 2005:42).

\subsubsection{The role of the principals: "incredible leadership"}

Many participants have used the opportunity to express their respect and admiration for their principal. Comments such as "a stunning principal"; "an excellent head, very involved"; "incredible leadership"; a "principal that is so humane"; and a principal who "has a passion for the growth of the school" express their admiration. They also 
view the professional support as "fantastic" and value the democratic leadership styles of their principals. As one participant explains:

Staff members can express themselves according to who and what they are. This 'freedom' to be yourself and to develop in a system that also has to function as a unity is projected onto the way the learners are seen and treated. Staff are invited en masse, in groups and individually to participate in decision making and in the running of the school. Staff members are constantly challenged to improve themselves and to learn new skills.

Participants value the positive attitudes of their principals. An example of such an accolade is: "The principal's positivity is infectious. It motivates me to do more than I might want to otherwise." Many of them also refer to the extend that the principals' behaviour influences everybody in the school: "Our principal's commitment and passion for education trickle through to everyone - parents talk about it and we attract more learners." Moreover, both the principals are committed to the continuous professional development of staff for the sake of learner performance. Numerous opportunities, which include motivational courses, PD workshops and self-improvement challenges, are provided to encourage professional growth among staff members.

The principals often acknowledge and recognise the valuable contribution made by their staff. They strive to protect, empower and motivate the staff to higher levels of performance, as confirmed by the principal of school B:

I add fuel to the flame; people get so little recognition ... When they [staff] excel or do something special, I say 'I'm proud of them, the school is proud of them' ... We give terrific recognition to one another. If there was a netball meeting yesterday, 'Thank you, ladies'; if there was a rugby meeting last night, 'Thank you, fellows'; 'Who was at the tennis? Thanks ladies; thanks for doing it'. Even the boring detail, so that everyone knows what's going on at school.

Principals are crucial to the smooth running of schools and have a major impact on teacher performance and learner achievement (Bernauer, 2002:90; Moswela, 2006). They set appropriate examples and act as role models for staff and other role players in the school (Hodkinson \& Hodkinson, 2005). Principals can provide individualised support through a motivational, supportive style of lea- 
dership which includes demonstrations of respect for individuals and concern about their personal feelings and needs (Heaney, 2004:42; Lee, 2005:46). They can also provide intellectual stimulation by challenging teachers to become more effective (Somers \& Sikorova, 2002:111; Mester et al., 2002:73).

The findings confirm the IE assumptions, in particular assumption one and assumption four. The first assumption refers to the way in which the principals respect the ability, value and responsibility of people, and the fourth assumption indicates how human potential is realised by the places, policies, processes, and programmes created in the schools to invite human development.

No school or process as such is perfect; they all require improvement. On the path to being an inviting school, all aspects must be improved continuously by altering, adding to, subtracting from and refining the difficult aspects in such a way that it leads to an even more inviting culture. The next section focuses on those aspects that participants believe need to be addressed to make the schools intentionally inviting.

\subsection{The dreaming phase: creating a new future}

Although a few participants have express their satisfaction with the current situation in their schools and feel that "nothing needs to change", they have nevertheless identified a new vision of areas that could improve in the future. One of the participants comments that "the status quo is good - but that means we have stagnated; there has been no growth", which proves the necessity to improve all systems in schools all the time.

In the next section, the identified categories of features that staff value in the schools are viewed in terms of future improvements. As has been the case with the subcategories in the discovery phase, in vivo codes are used in this section. These subcategories are: the school atmosphere: "Get rid of all negatives in the atmosphere"; developing a passion for working with kids: "becoming more inviting"; physical resources and the running of the school: "Take broad responsibility for overall picture of school system"; and leadership: "Communication between management and staff not satisfactory". The findings in all these subcategories are supported by the framework provided by $\mathrm{Al}$, and in particular, the simultaneity principle that states that the act of inquiry sets the stage for change (Dunlap, 2008:25) and initiates the discovery of possibilities for building the future (Lehner \& Hight, 2006:143). Since the sub- 
categories in this section are related to those in the discovery phase, the literature and conceptual framework that support the interpretation of each of those subcategories are also applicable to subcategories in this phase.

\subsubsection{The school atmosphere: "Get rid of all negatives in the atmosphere"}

It is clear from the evidence that participants appreciate the school atmosphere in which they work: the collegial and management support, the "spirit" that reigns in the school, and teamwork among colleagues. Unfortunately there are also negative experiences:

When you ask someone to do something for you, it's always a fight to get what you want. Everything has to be done and done right, but the [human] resources aren't always willing. It's also bad not to get to your people because there's not enough time or breaks.

Participants place a high premium on collegiality and suggest that even more opportunities for collaboration are needed. They recommend more time to interact and more team-building activities within the school. One participant writes, "I'd like to make more time for interaction with my colleagues, to find solutions in problem areas by discussing these with them ... Team building with colleagues will forge closer bonds."

According to another participant the "ideal is to create a learning atmosphere in which curiosity, good values, courtesy, et cetera are rewarded as the 'appropriate choice' for becoming intentionally more inviting".

\subsubsection{Developing a passion for working with kids: "becoming more inviting"}

Although many participants express their satisfaction with the way the schools approach learners, some of them also realise the necessity to "work on one's orientation to the children" and to change their "focus". One of the participants refers to her 30 years of experience and writes that changes are "very much needed ..." to become "a teacher whom learners will remember as someone who made a difference in their lives".

Developing teachers' passion for working with learners is mentioned repeatedly. Once there is a better understanding of learners' circumstances, especially those of "slow learners", staff will be in a bet- 
ter position to approach learners with empathy. Participants suggest that teachers should attempt to imagine themselves in every learner's situation ("placing myself in other people's shoes"); to "be there" for the learners - to be "more available"; to pay "more attention to positive learners than to trouble makers"; to conduct "personal interviews with learners"; and to motivate learners "by remaining cool and collected and positive". Many of them, referring to their approach to the teaching situation, suggest that they should "review and research" the subjects they teach "to make lessons more interesting"; "change a few things so that teaching and education can be fun again"; change their lesson presentation; and develop a positive attitude by reading motivational books. A few participants also acknowledge the importance of laughing in the classroom. In short, as one participant writes: "VERY IMPORTANT: to act inviting ... focus on what is best and most positive in each learner. They are the parents, teachers and leaders of tomorrow ... One's chief aim is the learner's total wellbeing."

Becoming and developing a more inviting school community includes the physical environment where all interactions in education take place.

\subsubsection{Physical resources and running of the school: "Take broad responsibility for overall picture of school system"}

Although participants appreciate their current physical resources and the running of the school as in the case of the previous subcategory, they also have views on how systems could be improved. Some of the participants believe that "aesthetic aspects" such as the school gardens, entrance, staff room, hall and playgrounds could be improved to become more inviting and child friendly. One participant complains about lawn mowers that make a lot of noise during schools hours. The noise makes the learners restless and the teacher edgy.

One of the schools does not have enough classrooms and office space since learners' numbers have increased significantly during the past few years. A participant makes the following comment:

Every teacher should have his or her own classroom or office. Having to move around is a headache. All staff members should have places of their own where they can relax and feel secure. Recharging in your own personal space is good for relationships and positive attitudes. 
Upon inquiring about this through member checking, one school has acknowledged that this is "a frustration we are trying to get under control". At present "the main subjects (English, Afrikaans, Mathematics) are firmly anchored" in classrooms while the auxiliary subjects (two periods per week) "get pushed around" and teachers need to conduct these lessons in the school hall.

Two participants acknowledge that they have a large school yet feel that discipline could improve. One of them points out that, to avoid loss of valuable time, class movements ought to be carried out more smoothy, even when big groups have to assemble.

Many of the participants also believe that their current reward system needs attention. One participant would like financial rewards for teacher performance. Another participant makes the following comment about the reward system for learners:

The feeling among the educators is that, while learners do get some rewards at present, they should be rewarded for good performance in a wider range of areas. When poorer learners show an improvement, however slight, there should be a reward of some kind.

Some of the participants acknowledge shortcomings in the way they run their own classrooms. They want to "tackle things in a new and different way", "investigate new methods of using time more effectively" and "find shortcuts, especially when it comes to red tape".

The principal of School B expresses the following view on the running of the school as a whole:

All staff members should buy into the dream and take broad responsibility for the overall picture of the school system. They [the teachers] should be understanding about decisions that transcend one's own responsibilities and not be apathetic about new projects. They need to think 'outside the box' and make suggestions (instead of complaints).

It is clear from the above that physical resources and the smooth running of schools have an effect on every role player. Leadership plays a key role in this regard.

\subsubsection{Leadership: "Communication between management and staff not satisfactory"}

Although the majority of participants praise their principals for their effective leadership, a few participants suggest ways of improving 
the current situation. Some of them refer to unmanageable workloads and unnecessary marking and assessment. One participant suggests: "Allow educators to stick to their calling - no irrelevant jobs like sweeping floors or wiping window panes. These things reduce work satisfaction."

Others would prefer fewer extramural activities to ease the workload of teachers. An area that participants believe could improve is the communication between management and staff. One participant comments: "I would like to see an effective system in place." Such a system would allow for more participative decision making, especially as regard to teachers' own retraining choices. It is clear that teachers prefer a democratic leadership style, without "prescriptiveness".

\section{Conclusion}

This study pursued the Al theoretical perspective to analyse staff's perceptions of IE as an example of PD. It entailed an inquiry that began with appreciation of what is currently working effectively in schools, to create an inviting school culture. It also offers consideration of points of future development in schools so that they may become intentionally more inviting. The findings are summarised in Figure 1, which indicates the contribution of the discovery phase (current practices relating to the IE model) and the dreaming phase (to motivate the schools to become intentionally more inviting) to the creation of a school culture that is more conducive to effective teaching and learning.

The discovery phase in the study reveals numerous positive aspects relating to IE in the schools' approach to teaching and learning. These positive aspects placed the two schools in an advantageous position to apply for the inviting school award from the International Award for Invitational Schools. Since the IE approach has not been intentionally applied, it was necessary to determine which aspects needed to be addressed in order to align the schools with the assumptions of IE. It was during a workshop on IE that schools were led to a clear understanding of how IE could be contextualised to meet the requirements of an intentionally inviting school. This article attempted to focus on staff's positive experiences regarding the current approach to teaching and learning in schools and the necessary strategies that may be introduced to assist staff and their schools in becoming intentionally inviting. It is however, recommended that a follow-up study should be done to determine the views of learners on the schools' attempt to create an inviting school environment. 


\section{Figure 1: Assessing current practices and exploring improvements to create intentionally inviting}

\section{What is: Assessing current best practices (discovery)}

A nurturing school atmosphere: "I come to school with a song in my heart"

good spirit, peaceful atmosphere, comradeship among teachers, collegial support, sense of belonging

Approach to learners: developing "a passion for working with kids"

"commitment" to and "passion" for learners, every child gets recognition, staff help learners to develop their full potential

Physical resources: "beautiful" schools, "good facilities", and "smooth running"

gratitude for the physical appearance of schools, excellent neighbourhood, small classes with personal attention to learners, good planning

The role of the principals: "incredible leadership"

principals "stunning", "excellent head, very involved", "humane", "positive", "incredible leadership"

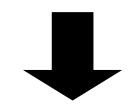

Main aim: To create intentionally inviting schools
What should be: Exploring to create intentionally inviting practices (dreaming)

The school atmosphere: "Get rid of all negatives in the atmosphere"

people are not always willing to work together, more time to interact and more team-building activities required

Developing a passion for working with kids: "becoming more inviting"

Staff should work on their orientation to children - have better understanding of learners' circumstances, pay more attention to positive learners, make lessons more interesting, develop a positive attitude

Physical resources and running of the school: "Take broad responsibility for overall picture of school system"

Aesthetic aspects can be more inviting, lawnmowers make a lot of noise - make staff and learners restless, not enough classrooms, discipline can improve, "Tackle things in a new and different way"

Leadership" "Communication between management and staff not satisfactory

Workload of staff requires attention, communication not effective, more joint decision making required

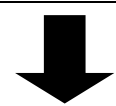


Aligning schools to become intentionally inviting implies the implementation of certain school development strategies to bridge the gap between where schools are and where they need to be in order to be inviting in their approach to teaching and learning. This also indicates that the quality of schools depends on the professional growth of staff, since school effectiveness and PD of staff in schools are closely linked. The majority of South African schools are acknowledged to be in "a state of disaster" (Bloch, 2008:19) or "in crisis" (Bloch, 2008:19; Paton, 2006:1) and this has a major impact on the quality of teaching and learning in such schools. By focusing on creating intentionally inviting schools, school cultures that are conducive to effective teaching and learning could be created.

\section{List of references}

ANON. 2007. What is professional learning? http://www.deet.nt.gov.au/ education/professional_learning/docs/what_is_prof_learning.pdf Date of access: 17 Aug. 2008.

ASBILL, K. \& GONZALEZ, M.L. 2000. Invitational leadership: teacher perceptions of inviting principal practices. Journal of invitational theory and practice, $7(1): 14-27$.

AUSTRALIA. Department of Education, Employment and Workplace. 2008. Teachers for the 21st century - making the difference. http://www.dest. gov.au/sectors/school_education/policy_initiatives_reviews/reviews/previo us_reviews/teachers_for_the_21st_century.html Date of access: 19 Aug. 2008.

BAROHNY, E. 2008. Making connections: grounding professional development in the developmental theories of Vygotsky. The teacher educator, 43(2):134-155, Apr./Jun.

BERNAUER, J. 2002. Five keys to unlock continuous improvement. Kappa delta pi record, 38(2):89-92, Winter.

BILLINGS, D.M. \& KOWALSKI, K. 2008. Appreciative inquiry. The journal of continuing education in nursing, 39(3):104, Mar.

BLOCH, G. 2008. SA in the midst of an education crisis. The Star: 19, 31 Jul.

BUSHE, G.R. 2007. Appreciative inquiry is not (just) about the positive. $O D$ practitioner, 39(4):30-35.

BUSHE, G.R. \& KASSAM, A.F. 2005. When is appreciative inquiry transformational? A meta-case analysis. The journal of applied behavioral sciences, 41(2):161-181.

CALBRESE, R.L., HUMMEL, C. \& MARTIN, T.S. 2007. Learning to appreciate at-risk students: challenging the beliefs and attitudes of teachers and administrators. International journal of educational management, 21(4):275-291.

CHALMERS, L. \& KEOWN, P. 2006. Communities of practice and professional development. International journal of lifelong learning, 25(2):139-156. 
COOPERRIDER, D.L. \& SRIVASTVA, S. 1987. Appreciative inquiry in organisational life. Research in organisational change and development, 1:129-169. http://www.appreciativeinquiry.org/Al-Life.html Date of access: 1 Apr. 2009.

CORBIN, J. \& STRAUSS, A. 2008. Basics of qualitative research. 3rd ed. London: Sage.

CRESWELL, J.W. 2007. Qualitative inquiry and research design: choosing among five approaches. 2nd ed. Thousand Oaks: Sage.

DARLING, L.F. 2008. Innovations in teacher education: a social constructivist approach. Canadian journal of education, 31(3):780-784.

DARLING-HAMMOND, L. \& RICHARDSON, N. 2009. Teacher learning. Educational leadership, 66(5):46-53, Feb.

DESIMONE, L.M., SMITH, T.M. \& UENO, K. 2006. Are teachers who sustained content-focused professional development getting it? An administrator's dilemma. Educational administration quarterly, 42(2):179-215.

DIXON, N.M. 1998. The responsibilities of members in an organization that is learning. The learning organization, 5(4):161-167.

DORING, A. 2002. Lifelong learning for teachers: rhetoric or reality? Challenging futures? Changing agendas in teacher education, 3-7, Feb. Armidale. http://scs.une.edu.au/CF/Papers/pdf/ADoring.pdf Date of access: 17 Aug. 2008.

DREHER, E.D. 2002. Leading the Toa: the energizing power of respect. The learning organisation, 9(5):206-213.

DUNLAP, C.A. 2008. Effective evaluation through appreciative inquiry. Performance improvement, 47(2):23-29, Feb.

DYMOKE, S. \& HARRISON, J.K. 2006. Professional development and the beginning teacher: issues of teacher autonomy and institutional conformity in the performance review process. Journal of education for teaching, 32(1):71-92.

EGLEY, R. 2003. Invitational leadership: does it make a difference? Journal of invitational theory and practice, 9:57-70.

ELLEVEN, R.K. 2007. Appreciative inquiry: a model for organizational development and performance improvement in student affairs. Education, 127(4):451-465, Summer.

GALLOWAY, H. 2004. Job-embedded professional development. http://www. txstate/edu/edphd/PDF/jobpd.pdf Date of access: 6 Apr. 2010.

GIORGI, A. 1985. The phenomenological psychology of learning and the verbal learning tradition. (In Giorgi. A., ed. Phenomenology and psychological research. Pittsburgh: Duquesne University Press. p. 23-85.)

GRESHAM, G. 2007. An invitation into the investigation of the relationship between mathematics anxiety and learning styles in elementary preservice teachers. Journal of invitational education theory and practice, 13:24-33.

HEANEY, L. 2004. Leading professional development: a case study. The international journal of educational management, 18(1):37-48.

$\mathrm{HIRSH}$, S. 2005. Professional development and closing the achievement gap. Theory into practice, 44(1):38-44.

HODKINSON, H. \& HODKINSON, P. 2005. Improving schoolteachers' workplace learning. Research papers in education, 20(2):109-131, Jun.

HONG KONG. EDUCATION BUREAU. 2006. Continuing professional development of teachers. http://www.edb.gov.hk/index.aspx?langno= 1\&nodeid=1309 Date of access: 21 Aug. 2008. 
HUNTER, M. \& SMITH, K.H. 2007. Inviting school success: invitational education and the art class. Journal of invitational practice and theory, 13:8-23.

INVITING SCHOOL AWARD. 2010. Inviting School Award 2010. http://www.invitationaleducation.net/Invitational\%20School\%20SurveyRevised/index2.shtml Date of access: 23 Mar. 2010.

KING, M.B. \& NEWMAN, F.M. 2001. Building school capacity through professional development: conceptual and empirical considerations. The international journal of educational management, 15(2):86-94.

KITCHEN, J. 2009. Relational teacher development: growing collaboratively in a hoping relationship. Teacher education quarterly, 36(2):45-62.

KOK, J.C. \& VAN DER MERWE, M.P. 2002. Invitational education: adding uniqueness - an empirical study. Paper presented at the 18th International Conference of the IAIE, Kennesaw State College, Atlanta, United States of America, 10, 12 October 2002.

LEE, H-J. 2005. Developing a professional development programme model based on teachers' needs. The professional educator, 27(1 \& 2):39-49, Fall, 2004 \& Spring, 2005.

LEHNER, R. \& HIGHT, D.L. 2006. Appreciative inquiry and student affairs: a positive approach to change. College student affairs journal, 25(2):141151, Spring.

LEWIS, J. \& VAN TIEM, D. 2004. Appreciative inquiry: a view of a glass half full. Performance improvement, 43(8):19-24.

LINCOLN, Y.S. \& GUBA, E.G. 1985. Naturalistic inquiry. London: Sage.

MAREE, K. \& VAN DER WESTHUIZEN, C. 2010. Planning a research proposal. (In Maree, K., ed. First steps in research. Pretoria: Van Schaik. p. 24-45.)

MARTENSSON, M. 2000. A critical review of knowledge management as a tool. Journal of knowledge management, 4(3):204-216.

MCMILLAN, J.H. \& SCHUMACHER, S. 2006. Research in education: evidencebased inquiry. 6th ed. Boston: Pearson.

MEIERS, M. \& INGVARSON, L. 2005. Investigating the links between teacher professional development and student learning outcomes. http://www. dest.gov.au/NR/rdonlyres/993A693A-3604-400F-AB81-57F70A

8A83A6/8039/Vol1Rev_Final_26Sept05.pdf Date of access: 21 Aug. 2008.

MESTER, C., VISSER, D., ROODT, G. \& KELLERMAN, R. 2002. Leadership style and its relation to employee attitudes and behaviour. Industrial psychology, 29(2):72-82.

MOSWELA, B. 2006. Teacher professional development for the new school improvement: Botswana. International journal of lifelong education, 25(6):625-632, Nov./Dec.

NEGRIONI, P.J. 2005. Another teacher professional development day? Lose another day of class time? Can we afford this? Journal of staff development, 26(1):58, 72, Winter.

NOVAK, J.M. \& PURKEY, W.W. 2001. Invitational education. Bloomington: Phi Delta Kappa Educational Foundation.

PATON, C. 2006. Education in crisis: a lot to learn. Financial mail: 1, 8 Sept.

PAXTON, P. 2003. Inviting e-learning: how hard can it be? Journal of invitational theory and practice, 9:23-40. 
PRESKILL, H. \& CATSAMBAS, T.T. 2006. Reframing evaluation through appreciative enquiry. Thousand Oaks: Sage.

PURKEY, W.W. \& ASPY, D. 2003. Overcoming tough challenges: an invitation theory of practice for human psychology. Journal of human psychology, 23(3):146-155, Summer.

RHODES, C. \& HOUGHTON-HILL, S. 2000. The linkage of continuing professional development and the classroom experience of pupils: barriers perceived by senior managers in some secondary schools. Journal of inservice education, 26(3):423-435.

SCHMIDT, J.J. 2004. Diversity and invitational theory and practice. Journal of invitational theory and practice, 10:26-45.

SCHUTT, D.A. 2007. A strength-based approach to career development using appreciative inquiry. Broken Arrow: National Career Development Association.

SMITH, C. \& GILLESPIE, M. 2007. Research on professional development and teacher change: implications for adult basic education. http://www.ncsall. net/fileadmin/resources/ann_rev/smith-gillespie-07.pdf Date of access: 21 Aug. 2008.

SOMERS, J. \& SIKOROVA, E. 2002. The effectiveness of in-service education on teachers' course for influencing teachers' practice. Journal of in-service education, 28(1):95-114.

VAN EEKELEN, I.M., VERMUNT, J.D. \& BOSHUIZEN, H.P.A. 2006. Exploring teachers' will to learn. Teaching and teacher education, 22:408-423.

VAN VEEN, K. \& SLEEGERS, P. 2006. How does it feel? Teachers' emotions in context. Journal of curriculum studies, 38(1):85-111.

VEMIĆ, J. 2007. Employee training and development and the learning organization. Economics and organization, 4(2):209-216.

VYGOTSKY, L.S. 1978. Mind in society: the development of higher psychological processes. Cambridge: Harvard University Press.

WENGER, E. 2007. Communities of practice. Third Annual National Qualifications Framework Colloquium, 5 June 2007, Velmore Conference Estate, Cape Town.

\section{Key concepts:}

appreciative inquiry

invitational education

primary schools in South Africa

professional development

qualitative research

\section{Kernbegrippe:}

kwalitatiewe navorsing laerskole in Suid-Afrika professionele ontwikkeling uitnodigende onderwys waarderingsondersoek 
